\title{
The Politics of Constitutional Change between Reform and Evolution
}

\author{
Nathalie Behnke* and Arthur Benz ${ }^{\dagger}$
}

In this article, we investigate the dynamics of constitutional policy. Starting from the observation that federal systems are confronted with a two sided dilemma of stability and flexibility, the question is how necessary constitutional change can be accomplished in spite of special rules of amendment and numerous veto players. We propose an analytical distinction of reform and evolution as two modes of constitutional change that can complement and in part substitute for each other. Comparative research shows that those two modes can effectively account for different patterns of constitutional change and that a two track mode of constitutional change making use of a flexible interplay of both reform and evolution can best secure federal stability over the long run.

In view of the dynamics emerging from a territorially differentiated structure and inherent in intergovernmental relations, it is the basic challenge of each federal system to find a stable and legitimized balance of power. To be sure, not only federal states, but also all political systems are concerned about their stability and legitimacy. But in federal systems, this concern is particularly acute, for stability is under a greater pressure, as illustrated by numerous examples of failed federations worldwide (Kavalski and Zolkos 2008). Destabilizing effects are caused by social, economic, and cultural developments affecting the balance of tasks and resources between governments (Livingston 1956), but particularly from centripetal and centrifugal tendencies due to a continuous struggle of actors in the different territorial units, all of whom are eager to increase their power (Riker 1964). If those forces are in disequilibrium, they may jeopardize the federal system, either by leading to a transformation in a central state or by secession. Even well-established federal systems are continuously challenged by dynamics of their structures that can cause problems of governance or legitimacy (Lemco 1991; Watts 1977).

While a legal approach to the study of federalism implies that stability has to be guaranteed by a constitution, political scientists have suggested extra-constitutional mechanisms or outlined structural conditions that should make a federal

*Fern Universitaet in Hagen, nathalie.behnke@fernuni hagen.de

†Fern Universitaet in Hagen, arthur.benz@fernuni hagen.de 
system robust. Some have proposed particular institutional designs (e.g., De Figueiredo and Weingast 2005); others have assumed stability depends on a societal consensus or a federal culture (Livingston 1956; Friedrich 1968), on intense communication inside a society (Deutsch 1957) or on commitment of elites or citizens to federal unity (Frank 1968). Riker's theory, that an integrative party system reduces incentives for federal and regional governments to change the balance of power to their individual profit (Riker 1964: 136) still finds acknowledgment among scholars (Filippov, Ordeshook and Shvetsova 2004). For multinational federations with divided societies, accommodation through elite bargaining has been recommended (Lijphart 1977). However, what have been suggested as provisions for securing stability are often structures or norms that depend on a stable federalism and therefore cannot support stability. Still, legitimacy for a particular allocation of power requires a constitution accepted by citizens. This is the reason why a written constitution assigning competences and resources to levels and institutions is usually regarded as a basic feature defining a federal system. Even if we take it for granted that a stable federal system needs to be supported by mechanisms enforcing the constitutional compact, the constitution expresses the rules that are valid and which are to be applied in politics. For this reason, even if a constitution cannot guarantee stability of federalism, constitutional policy has to be regarded as an important mechanism determining the balance of stability and flexibility of federal systems.

Federalism thus gives rise to a twofold tension between stability and flexibility: At the level of day-to-day politics, stability has to be enforced against shifts in power inherent in the interplay between governments at different levels, which in the extreme case, may lead to the dissolution of the federal order (Filippov, Ordeshook and Shvetsova 2004). At the same time, politics in a federal system must be flexible to react to changing conditions of policy-making. At the level of the constitution, the rules of federalism must be more stable than regular legislation and protected against too easy change. But in view of the dynamics of society and politics, it must be possible to adjust a constitution if the changing conditions require it. Otherwise, an overly rigid constitution jeopardizes the stability of the federal state in the long run (Watts 2008: 161-162).

Actually federal constitutions are often "inefficient but sticky" (Rodden 2006: 227). Formal constitutional amendments are usually difficult to achieve. On the one hand, rules of amendment assign the representatives of the constituent states rights of voice and sometimes of veto in constitutional negotiations. On the other hand, as constitutional negotiations mostly concern the allocation of competences and resources, they imply redistributive conflicts. It is thus very likely that a proposed constitutional amendment meets a coalition of actors impeding its passage, because each of them would be in some respect worse off under the new distributive scheme than under the status quo. Therefore, the problem of federalism 
is not only instability caused by continuous power struggles in politics, but also rigidity of constitutional rules due to those struggles (Bednar 2005).

Considering the complexity and variety of federal systems, to find a solution to this problem is a challenging task. Some initial steps have been undertaken in this special issue: Richard Simeon summarizes in his contribution the relevant factors that influence the probability and the outcome of constitutional change in federal systems and should be considered as variables in comparative research. The articles on selected countries outline in greater detail the processes of federal change under different conditions. In this article, we focus on the analytical differentiation between two modes of constitutional change: reform and evolution. The interplay between those two modes is essential for understanding constitutional change and evaluating the effective rigidity or flexibility of federal systems. It accounts for many empirical patterns of stability and change in federal constitutions. In the following section, we outline our analytical framework that allows us to address the complexity of constitutional change and to formulate preliminary hypotheses on the dynamics and mechanics of constitutional policy. We apply this framework in the comparative analysis of federal reforms and evolution in five selected states. In the final section, we identify and discuss different patterns of constitutional change.

\section{Analytical framework}

We regard a federal system as stable if the allocation of power and resources between the constituent units and their institutions is accepted by political actors of all levels. If this is no longer the case, destabilizing dynamics have to be corrected by constitutional change. Due to our focus on established Western Democracies, we do not deal with extremely unstable systems. In the light of such substantial crisis that countries like Iraq, Russia or Bosnia are currently undergoing, all Western Democracies under consideration appear to be very stable. Nevertheless, in the perception of actors in all federal systems, an instability or imbalance of the federal system regarding the allocation of power and resources, the claims for more autonomous rights of sub-national units, or the alienation of citizens from their government is often a triggering factor to induce a process of constitutional policy. This has also occurred in established federal states.

Federal constitutions are difficult to change even if this is necessary to restore stability. Existing theories on policy-making or institutional change tend to predict that constitutional amendments occur only very rarely and under very high odds. This is hardly surprising, as constitutions are generally protected in varying degrees of rigidity by special amendment procedures, by decision rules requiring at least qualified majorities, by multiple ratifying actors, or by declaring parts of a constitution as altogether unalterable. No matter whether a theory emphasizes the 
maximizing strategies of rational actors in bargaining over package deals and the high transaction costs of these negotiations (e.g., Buchanan and Tullock 1962; Cooter 2000: 52ff., Scharpf 1997), the high number of veto players as they are typically involved in constitutional reform (Tsebelis 2002), or more broadly the rigidity imposed by formal and informal institutions (Lutz 1995; Lorenz 2004), it would always predict that a constitutional change is a highly improbable outcome.

Empirically, however, we can observe that constitutional change occurs, and it occurs even quite frequently in most federal systems. In the past ten years alone, most established Western federal states have undergone major constitutional reforms aimed at a reallocation of power and resources between constituent states and the federation (Marks, Hooghe and Schakel 2008). On the other hand, quite a number of attempts to reform the federal constitution have either failed or ended without significant progress when compared to the needs or goals defined in the political process.

Even when reform attempts fail, this does not necessarily mean that no constitutional change is possible. Rather, empirical evidence reveals that "implicit change" often follows failed formal reforms (Voigt 1999: 145-176). The concept of implicit change has been introduced in theories of constitutional economics. It has been presented as an alternative to "explicit" constitutional change, which according to this theory, would be possible only if actors negotiated new rules under a "veil of uncertainty" concerning their positions and distributive effects (Buchanan and Tullock 1962). As these conditions rarely apply, economic theory would expect constitutions to evolve in an "implicit" way rather than to be changed by formal amendments. These considerations point out a necessary differentiation of modes of change. However, they offer no explanation for the conditions of success and failure of change. Moreover, theories based on this distinction do not regard the interplay of the different modes of constitutional change, although they are usually linked. In order to understand the development of federal systems and to assess their stability and dynamics, we have to analyze how both modes of constitutional change interact.

Explicit change is defined as an alteration of the written text of the constitutional document(s). Generally this takes the form of a constitutional amendment. Larger bundles of amendments that are decided upon in a special process (e.g., a committee, a series of hearings and the like) are denominated as constitutional reforms. Both types of explicit change are always subject to negotiation among political actors as well as formal ratification according to the procedures required by the constitution. In the process of constitutional negotiation, involved actors propose and evaluate different reform schemes. They tend to protect their power position and vested interests and can threaten to use their veto power to impede changes. The negotiated proposal for change has then to be ratified, either by members of parliaments or by individual citizens in a referendum. The ratifying 
actors, even if they have no negotiation power, have an implicit veto power set by ratification rules. Under particular institutional conditions, e.g., in parliamentary procedures, the process of ratification can itself be subject to negotiation, but in the end, decisions are made by counting aggregated votes cast independently.

Implicit constitutional change is first of all a residual category: it comprises those constitutional changes that do not affect the written text of the constitutional document(s). It goes beyond the application of constitutional law because it alters the meaning and effect of constitutional norms without changing the wording. Thus, it is more difficult to delineate it empirically. However, as a matter of fact, it necessarily occurs because constitutions are incomplete contracts (Rodden 2006: 37-38) that never precisely delimit the powers assigned to actors or institutions or the scope of decision rules. This allows actors holding offices to extend their power (Riker 1964; Filippov, Ordeshook and Shvetsova 2004). If implicit change happens illegitimately, it can destabilize and erode the federal balance. On the other hand, implicit change can effectively stabilize the federal system if it is either backed by legitimizing mechanisms or has the prospect of gaining legitimacy. If a modified constitutional status quo finds approval, this shall be termed constitutional evolution. One typical example of constitutional evolution is judicial sentencing or interpreting the constitutional text in a new fashion diverging from traditional interpretation. Also, political routines may change reflecting an altered societal understanding or a change of informal norms. Finally, laws or intergovernmental agreements can amend and alter the meaning of the constitution.

Constitutional evolution is often initiated by unilateral action, by parliaments making laws in areas of contested responsibilities, by governments using their budgets to shift the allocation of resources or to intervene in competences of other governments or by citizens, or governmental institutions bringing disputed cases to the constitutional court. However, legitimacy can only be gained through acceptance by political actors and society. As there are no clear rules defining when necessary support by politics and society is gained, the status and relevance of evolutionary changes may remain unclear for a long time. But this constitutional ambiguity may help to avoid serious conflicts jeopardizing the stability of federal systems (Foley 1989).

Our focus in this article is thus on the mechanisms and processes of constitutional policy that are activated in the perception of federal crisis, in balance or instability. We identified the two distinct modes or mechanisms of constitutional reform on the one hand and constitutional evolution on the other. Assuming that political actors are able to consciously activate the one or the other mode, it would be interesting to find out when political actors prefer a reform, when an evolution, and why this is so. In which way are the two modes interacting? And finally, which mode is more successful in solving the constitutional problems, and under which circumstances? 
As Richard Simeon has explained in his article in this issue, this complex process of constitutional change and its outcome may be influenced by a number of different factors. There is not one theory that comprehends all relevant aspects we have to take into account. Research has to be still more explorative than focused on testing hypotheses. Based on our definition and description of the two modes, existing theories of institutional change allow us to derive basic assumptions that can guide comparative research.

The success or failure of constitutional reform depends crucially on the negotiation constellation and the rules of ratification. Other things being equal, we expect a reform to restore stability, if new rules are negotiated in different, but linked arenas (parliamentary, intergovernmental, societal arenas). Such a constellation avoids the problem that "design actors" (Héritier 2007: 51) are fully identical with actors affected by constitutional change, without excluding the latter. It also assures that agreements will not result from exclusive bargaining in private meetings. Moreover, if constitutional and normal politics are differentiated but not separated in the negotiation process, actors are compelled to ground their argument in general principles rather than to bargain for individual interests (Elster 1995: 395). In a federal system, an appropriate pattern of negotiations can be created by particular combinations of intergovernmental and parliamentary arenas and by including associations, independent experts or citizens in constitutional negotiations. Presumably, prospects for successful ratification are higher when agreements are based on good reasons formulated in inclusive negotiations, whereas compromises and package deals bargained among governments are less likely to gain the wide approval needed in ratification. However, in the last resort, ratification depends on the number and heterogeneity of veto players (Tsebelis 2002). These factors are determined by the number of arenas that ratification has to pass and the decisions rules.

Without being based on explicit constitutional policy, the acceptance of evolution is problematic. Thus, in the long run even evolutionary changes need to be backed by some kind of formal acceptance. This can be given by judicial sentencing, by negotiating multilateral agreements, by issuing binding rules below constitutional level or by formal declarations of acceptance. However, as long as such formal approval is lacking, evolutionary change is unable to stabilize the federal system. When political actors choose consciously the evolutionary mode to adjust the constitution, the chances for success are higher when this process is in some way or another linked to formal mechanisms of constitutional reform. These considerations allow us to formulate a first assumption:

1. The crucial problem in the reform mode to be solved is to surmount the hurdles of negotiation and ratification, whereas the crucial problem of evolution is to gain legitimacy for the change effected. The way to solve these problems is by an appropriate institutionalization of the processes. 
A number of potential patterns involving explicit and implicit changes are conceivable: First, federal stabilization may be a consequence of successful constitutional reform although we expect this to occur only under specific conditions. Second, explicit changes can follow constitutional evolution, which makes them more likely to succeed (Héritier 2007). Third, in a number of steps of incremental informal change, constitutional evolution can lead to an adjustment of the federal order to external challenges and internal dynamics. But these changes are more likely to be accepted if they follow norms evolving in constitutional negotiations. Therefore, in case of failed reforms, it must be distinguished at which stage the reform attempt was stopped. If the negotiations produce no result, the reform process is likely to be blocked altogether. If, on the other hand, constitutional negotiations ended with an agreement but the reform is voted down in ratification, it is possible to continue an evolutionary process based on those negotiation results that find approval. Thus, our second assumption is:

2. Reform and evolution are not two mutually exclusive modes of constitutional change; rather they complement each other. Only a "two-track" process of constitutional change linking reform and evolution allows federal systems to achieve a stable balance of rigidity and flexibility.

Our third assumption relates to the explanatory factors for the choice or activation of one reform mode or the other. While obviously many different factors play a role, we try to single out those which are most influential. The rules of amendment are of importance because they define the number and weight of veto-players and thus the odds for a successful reform (Mueller 1999). When a constitution is very rigid, political actors will ceteris paribus rely rather on evolutionary processes because formal reform is highly unlikely. Irrespective of the number of veto players, their cohesion is also relevant for the chances of successful reform. When antagonistic partners discover common interests and are able to form coalitions, when they have a co-operative interaction orientation (Scharpf 1997: 84-89) and when they are able to compromise on general criteria, e.g., of fair distribution, a high number of veto players can nonetheless agree on an effective solution. Finally, in a federalizing country where powers are still strongly concentrated at the center, a formal reform is easier to accomplish than in a highly decentralized system where the sub-national units have extensive veto rights (Tsebelis 2002: 136). Also, reform is more difficult to achieve in an asymmetric federal system because the requirements by the sub-national units are highly diverging, and general principles can only rarely be applied to solve conflicts of interest or distribution (Agranoff 1999). From this follows our third assumption

3. The "choice" of a particular mode of constitutional change depends on a complex mix of external factors. The most important among them are the 
formal rules of amendment, the actual constellation of negotiation actors and the existing federal power structure.

In any case, the particular combination of reform and evolution is open to strategic action by governments and can be modified either by unilateral action or by cooperation. Although institutional constraints for implicit or explicit change vary between federal systems, the limited institutional determination of constitutional reform and the variability of the way in which modes of change are linked create opportunities for political actors to accomplish constitutional change.

In the following sections, we compare five case studies in order to identify different patterns of constitutional change. Our focus is on Western federations or federalizing countries which during the last decades went through processes of constitutional reform or evolution, although with different reform paths and outcomes. We selected the cases according to their variation on the "dependent variable", i.e., we included cases where we can observe different patterns of change with different results. Moreover, the countries compared in this article vary in their relations between levels of government and in the intensity and dimension of federal conflicts to be solved. This research strategy allows us to further elaborate our hypotheses on the interplay of reform and evolution as conditions for success and failure of constitutional change.

Those five cases thus cover a spectrum of modes of constitutional change ranging from almost exclusive reform processes (Switzerland) to exclusive evolutionary processes (Spain). The reform of the fiscal equalization scheme and assignment of competences in Switzerland between 1991 and 2004 is often regarded as the example of most successful reform in a formal as well as substantial sense. Also in Germany, between 2003 and 2006, a major constitutional reform of federal structures was accomplished, although observers doubt the substantial success of this reform. A federal reform was accomplished by the British Government between 1997 and 2000 when Parliament passed three devolutionary acts for Scotland, Northern Ireland and Wales. The impact of this reform varies between regions and led in the aftermath to adjustment by constitutional evolution. In Canada, attempts to comprehensive ("mega-constitutional"; Russell 2004) reform ended with agreements in constitutional negotiations (Meech Lake and Charlottetown Accords) that failed in the ratification process. These Accords gave rise to constitutional evolution by federal legislative action and intergovernmental cooperation altering the constitutional reality while leaving the text mainly untouched. Spain, finally, stands for a country where no constitutional reform of the federal structure was ever initiated. The allocation of power between levels of governments has been significantly modified in processes of evolution, triggered by constitutional reform in the autonomous regions. 


\section{Cases of Constitutional Reform}

Among the countries analyzed in this article, three cases have accomplished at least formally constitutional reforms of their federal structures. Therefore, they are used to illustrate the paths which explicit constitutional change can take and to identify conditions for reform. However, in order to explain these reform processes, implicit change, and constitutional evolution have to be considered, too.

\section{Switzerland}

Switzerland achieved two major constitutional reforms in recent years. This is all the more surprising, as the rules of amendment set relatively high thresholds majorities in both parliamentary chambers, in the cantons, and in the population according to Title 6, chapter 1 of the Swiss constitution. The first reform aimed at a comprehensive revision of the constitution in 1999, accomplished after decades of discussion and several initiatives. Although this task was very big as regards the number of issues addressed, it contained only a few highly disputed issues and ended with few substantial changes. In contrast, the federal balance of power and resources was subject to a constitutional reform of tasks and finances. It has been regarded as part of the constitutional revision but was developed in a separate process. Officially called 'Re-organization of Fiscal Equalization Schemes and the Assignment of Tasks and Competencies to the Federal and Cantonal Levels' (NFA Neugestaltung des Finanzausgleichs und der Aufgabenverteilung für Bund und Kantone), this reform entailed a high level of conflicting interests and concerned directly the federal structure and power distribution. It is therefore particularly interesting to understand why this reform was successful.

The NFA was initiated in 1991, when the Federal Ministry of Finance published a report on the financial transfers between the federal level and the cantons. The results were alarming, as it became evident that not only the overall amount of federal transfers to the cantons had increased significantly and proved rather inefficient, but also the gap between poorer and richer cantons had widened, since the richer cantons profited most from federal transfers (Wettstein 2002). Thus, all involved actors acknowledged an immediate need for action. Also, it was agreed that a reform of federalism meant to maintain and safeguard, even to strengthen cantonal powers against slouching centralization (Freiburghaus 2005). In 1994, the federal and cantonal departments of finance started to renegotiate the allocation of tasks and finances (EFD 2004). After effectively nine years of preparation, the Swiss Parliament passed the constitutional reform package in October 2003, a result that was confirmed by the required popular referendum in November 2004. At that time, critics suspected that the substance of the reform might fail because many of the disputed details of the new distribution of tasks and finances had to be elaborated in later laws. But even the second and third stages of the reform were 
passed by Parliament without any notable problems, which confirmed the success of the constitutional reform.

A number of conditions explain this outcome (see also Braun in this special issue). The process of constitutional negotiation revealed a relatively high consensus. This consensus was made possible by institutional conditions of Swiss consensus democracy, but also by a particular structure of the process. It was characterized by a clear distinction, but not separation between constitutional issues and ordinary politics and between negotiations on principles of the reform and on particular amendments of the constitution. The sequential negotiation moving from more general to more specific issues enabled the actors to develop a shared understanding of the general premises of the reform and an integrative organization of the reform process. Moreover, from the beginning, the reform approach was comprehensive in substantial terms. In contrast to reforms in Germany and the UK, it was common sense that a discussion of the fiscal equalization scheme could not be separated from a reconsideration of the distribution of tasks and competencies (Braun 2008). While such an approach ran the risk of becoming too complex or inducing bargaining on package deals, the separation of decisions on the basic principles in a first phase and the decision on the precise allocation of powers and on the rules of financial transfers in a second and third reform phase avoided both problems (Wettstein 2002). It was much easier to build large consensus in the first phase, which then restrained the leeway for defection in the second.

Furthermore, from the very beginning, the federal executive co-operated closely and at equal level with the conference of cantonal financial ministers, supported by a team of experts who provided a widely accepted theoretical basis for the reform program. Moreover, in accordance with the rules of Swiss democracy, all relevant organized societal interests were included in the negotiations. Again, this process followed a clear structure. At both stages of negotiations, the intergovernmental negotiations were linked to consultation with society in a loosely coupled way that enabled mutual adjustment of perceptions and preferences (Braun 2003, 2008; Vatter and Wälti 2003).

The cooperative orientation of the actors involved was enforced by the ratification rules. The threat of the referendum at the end of the process motivated the leaders of the reform project to build consensus among different political and societal groups. And, of course, even in a cooperative process, economic incentives played a role. Governments of the rich cantons that effectively lost under the new scheme of fiscal equalization accepted the reform after the socialist party had motioned to introduce a harmonized tax scheme. This motion was deemed likely to pass if the new equalization scheme should fail. As tax harmonization would cost some of the cantons a considerable amount of money when losing their status as tax oasis, they rather preferred the new fiscal equalization scheme. Furthermore, in 
order to persuade the cantonal governments, the Federal Ministry of Finance had promised generously to take on a large share of the reform costs (see Braun 2008). New instruments of inter-cantonal contracts protected the smallest cantons from territorial re-organization and gave the biggest cantons a means to promote their policies, even though those contracts weaken the cantonal parliaments (Rhinow 2003). However, bargaining never undermined the framework of principles and reasons justifying the reform. Finally, the length of the process was a relevant factor, too. During the thirteen years between 1991 and 2004, there was enough time to react to criticisms and to pacify unwilling actors, to negotiate package deals, and to stimulate public support for the project.

Given the institutional hurdles of a constitutional reform and the issues at stake, the simultaneous reallocation of powers and resources in the vertical and horizontal dimension was a remarkable outcome, and the reform changed the constitutional status quo significantly and not only marginally. It revised the allocation of powers between levels of government, established new rules of fiscal federalism, and designed a constitutional framework for cantonal co-operation. How these new rules will work in practice, especially whether and how the cantons will adjust their democratic processes to the requirements of contractual policy, is a matter of constitutional evolution. All in all, the constitutional reform contributed to stabilize the Swiss federation against tendencies towards centralization and fiscal imbalances.

\section{Germany}

The German reform process appears similar to that in Switzerland in terms of instability problems. In both cases, the widespread perception of an inefficient allocation of competences and finances induced constitutional policy. However, in Germany, the critique focused on co-operative federalism and, consequently, reform aimed at disentangling legislative competencies and at reducing the veto power of the Bundesrat representing the Länder governments in the federal legislature. The German process also ended with a ratification of a constitutional reform in 2006, when the proposals received the necessary majority of two thirds in both chambers. Considering the articles of the constitution amended, this was the largest constitutional reform in the history of the German Federal Republic, even compared with the 1994 revision of the constitution after German unification. However, observers doubt the substantial success of the reform (Burkhart in this issue; see also Benz 2005, 2008; Scharpf 2005, 2006; Auel 2008; Hrbek and Eppler 2005). The goal of significant disentanglement of competencies was not met, and the re-organization of the fiscal constitution was excluded altogether. Whether the new rules for federal legislation will really lead to a significant reduction of the number of laws subject to the veto of the Bundesrat is disputed 
(Georgii and Borhanian 2006; Burkhart and Manow 2006; Risse 2007). A second reform covering fiscal matters is under way, but prospects for a significant change are dismal.

The working of the German federalism had been under critique for many years. Since the 1980s, the aim of constitutional policy on the part of the Länder was to decentralize powers and to push back federal interventions in affairs of Länder and local governments. The federal government, on the other hand, criticized the Bundesrat for abusing its veto power for party political purposes by often threatening or actually blocking legislative decisions. Thus, both levels had an interest in federal reform, although from different viewpoints. They jointly initiated the reform, but without coming to a consensus about the general conception and the aims.

In 2003, the federal parliament and the Bundesrat established a bicameral commission determined to elaborate proposals on how the system of interlocking politics could be disentangled. The commission was composed of equal numbers of members of the Bundestag and the Bundesrat. Experts and representatives of the Länder parliaments and of local governments were invited, yet given no voting rights. The negotiation process was dominated by intergovernmental bargaining, with a clear confrontation between the federal government on the one hand and the Länder governments on the other. This explains why the process started with the paradigm of disentanglement, empty in meaning as it is, and with an attempt to come to a package deal (Benz 2005). The federal government should concede legislative powers to the Länder and in turn gain a significant reduction of veto power of the Bundesrat. Procedural rules applied in constitutional negotiations fostered intergovernmental bargaining, too. When real conflicts were at stake, the commission discussed behind closed doors, and no attempts were made whatsoever to include societal groups. Constitutional negotiations failed when in December 2004 the commission terminated its work without presenting a proposal for constitutional reform.

In informal contacts, leading members of both levels and the grand parties continued negotiations and officially resumed them after the federal election in autumn 2005 had led the Christian and Social Democrats to form a Grand Coalition (Hrbek 2006). After a final controversial debate on some reform issues during a major parliamentary hearing, the constitutional reform was ratified by both chambers of the legislature in June 2006.

At first, the German process may seem to be an example of pure reform, like the Swiss reform. In fact however, it was strongly influenced by the Constitutional Court, which led to implicit change. The Court had provided the impetus to reverse a trend of federal dynamics from strong unitarization towards diversity and decentralization. With its decisions concerning concurrent competences it had given the Länder a much stronger position vis-à-vis the federal level, thus putting 
the federal level under pressure to (re-)act and to revise the constitutional text in face of the modified constitutional reality (Scharpf 2006). Moreover, the Court recently revised its previous decisions on fiscal autonomy of the Länder when it declined a constitutional right of debt-ridden Länder to be bailed out by the federal government, an issue that is now high on the agenda of the second reform commission. This interplay of Court decisions and constitutional amendment is not unusual in German federalism. In a constant situation of strong party political conflict overlapping the negotiations between the federal and the Länder governments (Lehmbruch 2000; Scharpf 1988), issues at stake are often framed in constitutional terms so that governments and parties, compelled to win in a dualist party competition, can justify concessions in bargaining by referring to "higher" norms, tightening the interconnection between ordinary policy making and constitutional policy. On the one hand, the Constitutional Court is often used as an arbiter of conflicts between governments, and constitutional amendments or reforms react to court decisions rather than constituting an independent mechanism of change. On the other hand, constitutional negotiations reproduce the power distribution of ordinary intergovernmental politics and are therefore strongly influenced by governments bargaining for institutional interests, as well as by policy-specialists in ministries and legal experts of Länder governments. As a result, constitutional change has mostly been driven in an evolutionary manner through Court decisions, while processes of reform followed the same logic of political bargaining which makes German federalism inflexible under the pressure of redistributive conflicts. Under these conditions, it is hard to effectively change the structures of the federal system, and German federalism is doomed to lose its flexibility (Benz 2008a).

\section{United Kingdom}

The United Kingdom is not a federal state and the devolution that we consider in this section is not a typical case of constitutional reform in federal systems. However, the change was driven by the dynamics of power typical for federalism, and the reform concerned a redistribution of power between levels of government. What makes this case interesting in a comparative study on constitutional change in federal systems is the institutional peculiarity that a central parliament can change the constitution with simple majority usually held by only one political party. In principle, we should expect successful reform to occur. In fact, the emerging dynamics of intergovernmental relations complicated constitutional change.

National movements in Scotland and-to a lesser intensity-in Wales and violent conflicts in Northern Ireland clearly signify instability in the UK. When in 1997 Labour party returned to government, the constitutional reform was a top priority of its political agenda. Alongside with other matters of constitutional 
reform (Trench 2008: 10; Johnson 2004: 169-170), administrative and in part political devolution not only in Scotland, but also in Northern Ireland, Wales and England was envisaged. With the passage of the three devolution acts for Scotland, Wales, and Northern Ireland in 1998 and positive referenda in the devolved regions, a far-reaching constitutional reform was accomplished within a breathtakingly short time span that effectively altered the political and administrative structure in the UK. The referenda gave the reform a strong legitimacy, protecting it from being easily reversed by the next government.

Due to parliamentary sovereignty and the unwritten British constitution, constitutional changes are not subject to a particular reform procedure, require no qualified majority, nor are they decided in specialized institutions. In formal terms, laws changing the constitution are undistinguishable from any other law passed by Parliament in everyday politics. Thus, it is not surprising that the Labour government with its clear parliamentary majority could initiate explicit constitutional change unilaterally and accomplish the reform, while the Conservative party interested in maintaining the unity of the state had little power. In contrast to the other cases under consideration, the relevant conflicts in the reform processes emerged not between the central government and provincial interests, but rather between political camps within the affected territories, most notably in Northern Ireland, but also in Scotland. And that is also where negotiations preceding constitutional reform took effectively place. This altered the role of the central government from being a direct player with vested interests towards acting as a broker among adversary parties at the provincial level. The consequences are revealed in the outcome of the reform and the further evolutionary development of the constitution (see Jeffery, in this issue).

The need to account for regional political, societal and cultural diversity led to an asymmetric federalization. Not by coincidence, devolution was enacted by three clearly distinct reform laws, the Scotland Act, the Northern Ireland Act based on the Belfast Good Friday Agreement, and the Government of Wales Act. The acts differed considerably as regards the competences and election rules of the regional parliaments, the catalogue of functions devolved and the degree to which the central government remained involved in the regional policy-making. While Scotland received the farthest reaching rights of autonomy, almost no legislative rights were given to Wales, and Northern Ireland remained under close scrutiny, the promised competences being subject to the regional parties proving able to collaborate peacefully. But obviously the asymmetric distribution of autonomous rights triggered - at least in Wales - a dynamic intended to extend the competences to a similar degree as in Scotland which was mirrored in several updates of the initial Act. In this way, the 2004 report of the Richard Commission and the 2006 Government of Wales Act are expressions of the evolutionary development of Wales as a devolved region with increasing rights of autonomy. 
Moreover, the initial devolution acts left many details unresolved, not least because several political imponderabilities could not be solved from the very beginning. The new constitutional framework made it necessary to specify regulations in the aftermath of the reform by mutual adjustment of central and regional institutions. The effective allocation of powers and the relations between the central and the regional levels were defined by agreements, set out in a Memorandum of understanding for each region. Concordats between the Department of Constitutional Affairs and the Scottish and Welsh Assemblies were meant to guarantee good and effective relations between the executives of both levels. "It was apparent that any change in constitutional powers and roles would be evolutionary" (Bradbury 2006: 579).

A decade after the initial reform, its success is doubted heavily (Trench 2008; Devolution Programme 2008). The Northern Ireland Assembly is still seeking to stabilize the consensus among the parties finally achieved in 2007, and in Scotland and Wales, although there is meanwhile widespread public support for further devolution, there is also a lot of disappointment about the limited policy impact of the reforms that have taken place so far. Discussions on devolution of power to the regions in England ended without results. Obviously, the reform was only a starting point for a long lasting process of constitutional evolution, the impact of which on the stability of the political system is still uncertain.

\section{Cases of Constitutional Evolution}

The three case studies on constitutional reforms show on the one hand that reforming a federal constitution is not impossible. Even when the rules of amendment set high thresholds, as in Switzerland or Germany, this does not necessarily cause constitutional rigidity. On the other hand, as revealed by the case of the federalized UK, constitutional reform alone cannot make a federal system work, but rather it needs to be complemented by evolutionary adjustments. Formally, successful reforms can miss the target, as in Germany, and in any case, constitutional reform can fail. Thus, a closer look at the evolutionary mode is indispensable for an encompassing understanding of constitutional change.

Canada and Spain represent federal systems showing dynamics of the federal balance without constitutional reform. In Canada, attempts to reform the constitution ended with negotiated agreements, which were rejected in ratification. In Spain, despite serious constitutional disputes, no process to amend the federal constitution has been started so far, but change occurred through unilateral actions by the Autonomous Communities and through negotiated agreements between central and regional governments. In both countries, the combination of rigid amendment rules and intense conflicts between the federal government and regional nationalities explain blockades, and constitutional evolution was clearly 
more important in changing the constitution than formal reforms. Therefore, these two examples can help to understand the ways in which evolutionary changes may contribute to successfully adjusting the balance of a federal system.

\section{Canada}

Canada's constitutional development since the 1930s was characterized by a number of amendments, but more by constitutional evolution. Both were driven by the increasing assertiveness of the provinces. But it was only in 1982, after the federal government took the lead and initiated the Constitution Act of the federal parliament, that the Canadian constitution was "patriated". With this act, an amendment formula and a Charter of Rights and Freedom were introduced. The amendment rules confirmed the veto power of the provinces as they require the consent of a qualified majority of the provinces; for a change of basic elements of the federal system unanimity is necessary. The Charter, by emphasizing individual rights against rights of communities, increased the divide between the federation and the province of Quebec (Brouillet 2004).

Later attempts to solve the serious tensions in the multinational federation by constitutional reform ended with intergovernmental agreements, which were rejected in ratification (Russell 2004). The Meech Lake Accord, negotiated in the usual patterns of intergovernmental relations among executives, was not approved by all provincial parliaments when the three-year ratification period expired in 1990. In 1992, after a sequence of negotiations in parliamentary committees at the federal and provincial level, intense consultation with societal groups and intergovernmental negotiations, the Charlottetown Accord was settled (Russell 2004: 163-189; Stein 1997). It defined principles, aims, and rules for a revised constitution. But, it was voted down in a referendum, which was inadequately prepared by the political elites. Also with a negative vote ended two referenda on a secession of Quebec in 1980 and 1995. All these decisions cumulated in a blockade of constitutional reform.

However, after the federal system had gone through a serious crisis, the constitution was successfully adjusted by evolution. The "constitutional fatigue" in Canadian society, caused by negative outcome of extensive constitutional consultations, compelled political leaders to deal with problems of the federal system without reform (Lazar 1997). Federal legislation and decisions of the Supreme Court, but in particular negotiations between governments in the so called "executive federalism" made this possible. The agreements in constitutional negotiations yielded the guidelines for these processes. Thus, while the constitutional reform ended in a deadlock, constitutional evolution continued, with remarkable results.

The most important changes of the Canadian federation since the Charlottetown Accord were achieved by intergovernmental agreements. This way, the regulations 
of inter-provincial trade have been coordinated and the spending power of the federal government was regulated in the Social Union Framework Agreement. The concerns of Aboriginal people have been dealt with in a number of agreements on land claims and self-government. Conflicts between the federation and Quebec are still at stake, but the federal parliament and all provinces explicitly accepted the distinctness of the province. The issue on the secession right of provinces, disputed between the federal government and Quebec, was regulated by a decision of the Constitutional Court and a federal law. Quebec still claims acknowledgement of its particular status in the constitution. In ordinary policy-making, this issue has been left in the background and handled in a pragmatic manner. The government of the province has opted out from some important federal programs but has participated in intergovernmental negotiations. Thus, the conflict on the status of the province has shifted to the background and became what Michael Foley called a "constitutional abeyance" (Foley 1989).

Still, important constitutional questions remain. The representation of the provinces in the Senate is under debate. Moreover, the agreements among governments are not always implemented in a sufficient manner and-although they are acknowledged as conventions or have quasi-constitutional character (Poirier 2004) — they cannot be enforced like constitutional law. Nevertheless, the ongoing process of constitutional evolution has contributed to overcome the crisis of Canadian federalism. This flexibility is usually explained with the rather intense and effective intergovernmental negotiations (e.g., Simeon 2006). However, the direction and substantial results of the evolutionary process must be traced back to the constitutional negotiations and the agreements resulting from them. It is the interplay of constitutional negotiations, blockades due to ratification failure, and effective intergovernmental cooperation following the guidelines of constitutional agreements, which contribute to effective and legitimate change of Canadian federalism (Benz 2008b).

\section{Spain}

Like in the UK, constitutional change of the Spanish federal system has been triggered mainly by unilateral legislative decisions. In contrast to the UK, where the constitutional framework was reformed by the national parliament and where the ensuing negotiated mode of evolution was led by the central government, the Spanish federal constitution evolved through a conflictive process induced by unilateral actions of competing regional governments. While no constitutional reform of the federation has been initiated so far, change has been triggered by Autonomous Communities.

Also here, as in Canada, evolution appeared as a strategy to circumvent a blockade of constitutional policy in a multinational country. Quite in accordance 
with the flexible system of assigning powers to the regional level introduced with the Spanish Constitution of 1978, parliaments of the Communities adopted powers from the centre (Moreno 2001). This induced a dynamic process of decentralization, in which the "Historical Nations" played the role of vanguards, since they claimed to represent autonomous regional societies. Other Communities followed in the adoption of competences from the centre and evolved into autonomous regional governments with their own statutes. These quasi-constitutional regional basic laws were negotiated with the central government and thus accepted as elements of the federal constitution. Given the dynamics of this process, which was supported by competition between regional governments, constitutional evolution led to far-reaching decentralization of powers without any reform of the federal constitution.

Since 2005, the five historical Autonomous Communities challenged the existing constitutional order, and Catalonia introduced a comprehensive reform of its statute (see Colino, in this issue). Regionalist parties that succeeded in elections pushed for these reforms to increase the power of the regions and to re-establish their special status as nationalities in the Spanish federation. These activities caused serious conflicts with the government in Madrid. After long and difficult negotiations, an agreement was reached between the central government and Catalonia. This agreement, adopted by the Spanish parliament and Senate in 2006, proves the flexibility of the Spanish constitutional order. However, the central government had to concede financial resources and competences (for details, see Colino, in this issue), without gaining influence on the dynamics of decentralization. Intergovernmental agreements, which in Canada provide for stability, are still emerging and are not yet well developed in Spain. Moreover, given the considerable change of the federal system via bilateral arrangements, the pressure for constitutional reform has increased. For these reasons, Spanish federalism remains rather dynamic, but still implies serious problems to keep the federal bargain (Colino 2006: 402-403).

\section{Patterns of Constitutional Change in Comparative Perspective}

Based on our five case studies, we cannot say that one or the other particular variable accounts solely for a certain outcome of constitutional change. Obviously, different combinations of variables have to be considered when we look for explanations (see Simeon in this issue). However, the cases offer an illustrative array of patterns of constitutional change leading to different results. Thus, they suggest certain interpretations and at least a preliminary evaluation of the assumptions formulated above.

\section{Institutional Provisions for Successful Change}

As was stated in the first assumption, effective constitutional change needs to be secured by appropriate institutional provisions for reform and evolution. 
In the case of reform, we emphasized the structure of constitutional negotiation and the rules of ratification, in the case of evolution, legitimacy of the changes is of decisive relevance.

One important aspect in structuring the reform process is the separation of arenas. Reform processes in Switzerland and Canada were negotiated in an institutional setting which differentiated constitutional and normal policy-making. In both cases, the negotiation process involved public and private actors at different stages. Devolution in the UK resulted from legislation according to the rules of normal politics, and it ended with a significant step towards federalization of the state, without solving conflicts on powers and resources. In Germany, reforms were negotiated without differentiating the arena of constitutional politics from that of normal politics and in a committee, reproducing structures of intergovernmental and party political bargaining. Besides separate arenas, effective and legitimate reforms apparently require also a sequencing of the process. In the successful NFA process, an initial phase with broad public involvement and an open discussion of different proposals was followed by a phase of exclusively executive intergovernmental decision-making, which helped to build consensus and enabled compromises.

A further aspect besides the structure of negotiations of reform proposals is the linkage between the negotiation and ratification processes. In anticipation of the required referendum, the promoters of the NFA process in Switzerland had engaged early in a broad discussion including diverse societal interest groups, parties and representatives of the different levels of government. In Canada, where the Charlottetown Accord failed in a consultative referendum, governments had organized a broad public discussion to define the agenda of constitutional reform which stimulated change, but then the Accord was settled in intergovernmental negotiations, and the governments made only insufficient efforts to communicate the results to the public. Thus, instead of confirming a consensus among the federal and the provincial governments, citizens expressed their discontent, rendering a unanimous approval by the provincial parliaments impossible. In Germany, the composition of the reform commission reproduced the power relations of veto players in parliamentary ratification. Thus, processes of negotiation and ratification were closely linked. However, it was exactly the reproduction of the conflict structures as they exist in day-to-day politics that inhibited a compromise in the negotiation process and turned it into ineffective intergovernmental and party political bargaining. For the British Government, ratification presented no real problem. In that particular situation, the referenda in the devolved regions were not regarded as a substantial hurdle, as London responded with the devolution laws to a demand forcefully expressed by the regions. For this reason, neither extensive negotiations nor public involvement were deemed necessary in order to prepare the referendum. 
Looking at the instances of evolution, it is less obvious how legitimacy of evolutionary changes could be secured. The evolutionary process in Canada which followed the Charlottetown Accord basically gained its legitimacy from decades of constitutional negotiations and an accord which included widely accepted guidelines for change although the reform had failed. Many solutions which had been drafted during constitutional negotiations were implemented later in intergovernmental agreements, declarations of the federal parliament or decisions of the Constitutional Court. Thus, one backing mechanism for evolutionary change can be a negotiated consensus, even though this has not manifested in constitutional reform. Another mechanism can be a successful reform, as in Switzerland and the UK, setting the framework for evolutionary change. In both cases, formal reforms defined general constitutional principles, which had to be implemented in intergovernmental negotiations or legislation following the reform. A third mechanism is constitutional adjudication. Where Constitutional Courts decide on disputes between subunits and the national level, they can give (or withdraw) legitimacy to existing practices. This happened in Germany and also in Canada, and if it happens in Spain, this will certainly provide strong legitimacy to the evolutionary changes, which remain so far in limbo.

To sum up, regarding the conditions of stable and legitimate constitutional change, the case studies emphasize the importance of institutions and actor strategies in structuring the change process. An institutional differentiation between constitutional policy and ordinary policy, between constitutional negotiations and ratification and between discussion and decision is conducive to successful reform. However, in federal systems we should never expect that these factors guarantee a positive result. If competitive relations between constituent units are allowed to trigger implicit constitutional change, yet if they are tamed and turned into legitimate evolution by an appropriate management of inter-jurisdictional conflicts in established patterns of intergovernmental cooperation, then federal stability can be secured in the long run. The normative principles guiding such an evolutionary process can be deduced from adjudication of constitutional courts, but for real change to occur, legitimacy drawn from constitutional agreements seems to be essential. For this reason, both modes of change have to be linked.

\section{Interplay Between the Two Modes of Change}

Accordingly, we stated in our second assumption that a "two-track reform path" is necessary for successful constitutional change, at least in the long run. In essence, this means that neither reform nor evolution can very well stand alone. Instead of being mutually exclusive alternative modes, they complement each other. There is, however, no single best way of combining both modes of change. In a comparative 
perspective, different links and sequences in the interplay between constitutional reforms and constitutional evolution come into view.

A first sequence conforms to the classical idea of a hierarchy of constitutional principles implemented in more detailed rules. In real politics this rarely occurs. The reforms in Switzerland and the UK seem to conform to this pattern of change. But reality is more complicated. In both countries, elements of the new constitutional rules have emerged in practice before they became entrenched into constitutional law. Moreover, only in Switzerland do we observe a process that started from determining the guiding principles and continued in their application in constitutional reform, with negotiations leading to some adjustments of principles without watering them down by political bargaining. In the UK, the sequence of constitutional reform and evolution followed the logic of a hierarchical power structure in the centralized state, which changed after the Devolution Acts. Without a coherent concept of reform, constitutional change turned into "piecemeal reform" (see Jeffery, in this issue) and incremental adjustments to different conflicts in Scotland, Wales and Northern Ireland while ending without progress in England.

Germany and Canada show different patterns of linking constitutional reform and evolution as overlapping processes. In Germany, reform and evolution are closely linked as both processes are shaped by similar structures of intergovernmental relations. Reforms ended with incrementally modified structures and procedures. Decisions of the Constitutional Court, initiated mostly by Länder governments, are important to influence the constitutional status quo. Governments reacted to these developments by adjusting the formal constitution. This cycle of Court decisions and constitutional amendments did not change the federal system significantly, but extended the constitutional regulations binding politics of German federalism. In Canadian federalism, due to amendment rules, constitutional reform and evolution are more clearly distinct processes. Development since the 1960s could be regarded as an alternation between implicit change and megaconstitutional reform, whereby failure of one mode has been replaced by the other. However, both modes of change were linked through agreements in constitutional negotiations that provided the agenda and guideline for legislation and intergovernmental agreements after the failure of reforms. This kind of linkage created more dynamics and effective change than we observe in German federalism (Benz 2008a, 2008b).

Such guidelines of a negotiated agreement are lacking in Spain, where implicit change results from competition among Autonomous Communities for more power to which the central government has to react. In view of the conflicts that may burden a constitutional discussion it seems to be prudent for a government to avoid reform as long as necessary changes can be achieved by implicit change. However, while in Canada governments can rely on a "permissive consensus" for change without reform, it is uncertain whether such a basis of legitimacy exists 
in Spain. Decentralization triggered by unilateral action of some Autonomous Communities leads only to a stabilizing evolution if it is supported by approval of diversity in the federation, as is the case in Canada.

A change of mode or an alternation may be in many cases a promising strategy to circumvent potential blockades which emerge from the structure of the constitutional problem. However, evolution may be constrained by patterns of intergovernmental relations. Joint decision-making among actors who compete for resources or voters, as is the case in Germany, may limit the room for adjustment while simultaneously exerting severe pressure for change. Asymmetric structures of powers between the national and sub-national levels limit adjustment, too. On the other hand, intergovernmental competition may cause uncontrollable dynamics, as in Spain and to a certain degree in Canada. Thus the choice between constitutional reform and evolution is not utterly unfettered, and under particular circumstances there is no alternative to reform. Presumably, stable federal systems combine elements of competitive and cooperative federalism as well as a "dualist" conception of politics (Ackerman 1991: 6-33) combining evolution and reform as two distinct and structurally differentiated, but functionally linked tracks of constitutional change.

\section{Determinants for the Choice of Constitutional Reform or Evolution}

Third, we assumed that the choice of one mode is strongly influenced by institutional, situational and structural factors. Three preliminary results deserve to be highlighted: Looking first at the role of the formal rules of amendment, we find mixed evidence. At a very general level it seems fair to say that where the rules of amendment set prohibitively high thresholds, constitutional reform is very unlikely to occur, and evolutionary change will prevail instead. This is the case in Canada and Spain, where formal reform of basic elements of the federal system is almost impossible to accomplish due to the rigidity of the constitution. In theory, one might also expect that amendment rules requiring a high threshold of majority make reform less likely and increase the probability for evolutionary change. But this is not supported by our comparative analysis (see also Lorenz 2004). Rather, when a constitution can be changed at all, the degree of rigidity does not seem to matter much. Switzerland has a more rigid constitution than Germany's; nevertheless it was reformed successfully, and there is no significantly higher degree of success in the British reform, although there is no formal threshold for constitutional change. Of course, amendment rules may contribute to a failure of reform, but their impact is more indirect and depends on the way they influence strategic action in constitutional policy and constitutional negotiations as was argued above. If actors involved in constitutional negotiations control the ratification process (as it is the case in Germany), formal constitutional amendments 
can be achieved by compromises in bargaining, whereas ratification by parliaments in the constituent states or by referenda compels actors elaborating a reform proposal to come to a consensus based on convincing reasons (like in the Swiss case) or they fail (like in Canada).

Second, the rules of amendment cannot account alone for the reform outcome, rather their impact is mediated by other factors. When there is a strong conflict of interest between decisive actors in a federal system, a reform may appear as a futile endeavor. On the other hand, where actors can agree on common goals and problem definitions, even high thresholds of ratification can be overcome, as in Switzerland and Germany. Also in the UK, there was no real conflict of interest between the central government and the devolved regions. The regions had pressed for a constitutional reform, a request that had been taken up by the newly elected government. In Spain, in contrast, there is no chance for the central government to initiate a reform as long as the Autonomous Communities do not support it and prefer to change the constitutional reality by decisions on their Statutes of Autonomy. In Canada, finally, the failure of the Charlottetown Accord caused a "constitutional fatigue" in politics and society that affected decisions of governments on constitutional policy.

Third, our examples underpin the impression that where and when a formal reform is possible, it is the preferred mode. Where reform is impossible or fails, evolution is activated as a complementing or compensating mechanism. Certainly, reform is the first instrument on which political elites rely, when a process of constitutional change is initiated at the federal level, whereas unilateral initiatives by sub-national units tend to result primarily in evolutionary change. Still such initiatives can put pressure on the national government, inducing it in a second step to concede a constitutional reform, as evidenced by the UK and Canada, and will probably happen in Spain.

If this conclusion finds support in further research, i.e., if reform and evolution are not determined by prevailing factors but by a variable set of conditions, both should be regarded as complementary ways to stabilize federal systems that can be applied by governments in a strategic way. As a consequence, strategic options are increased by a combination of these modes of change. This is the reason why we deem the interplay between reform and evolution as of utmost relevance.

\section{Conclusion}

In this article, we emphasized the analytical distinction of constitutional reform and evolution as two distinct, yet interdependent modes of legitimate constitutional change. To our knowledge, although the distinction between implicit and explicit constitutional change has received some scholarly attention (see e.g., Hönnige, 
Kneip and Lorenz forthcoming), a differentiation of modes of change has not yet been used to analyze and explain patterns of constitutional change in greater detail. Exactly for this purpose, however, it has proven to be a powerful analytical tool. In the five case studies presented here, the distinction of the two modes helped to understand the dynamics of different examples of constitutional policy and to explain different patterns of change in federal or federalizing systems.

We have taken some initial steps in identifying determining variables for the preferred use of the one or the other mode, and we have analyzed several different patterns of the two-track process of change. In the light of the fundamental dilemma of federal states that we outlined in the introduction - namely that between stability and flexibility - we would dare some concluding reflections on the dynamics of processes of constitutional change and their success in terms of federal stability.

In securing federal stability, Switzerland and Canada displayed the most successful patterns of constitutional change. In both cases, carefully balanced intergovernmental agreements were successfully implemented, either by means of a formal reform or, as in Canada, in a stepwise evolutionary process. In both countries, constitutional change was initiated and negotiated in an institutional setting that deviated from normal intergovernmental bargaining and included parliaments and civil society in different arenas. The development of Canadian federalism proves that evolutionary change can gain legitimacy if a reform fails due to problems in ratification. In contrast, Germany provides a case where formally successful reform has caused more stagnation than stability. Despite a number of amendments of the constitution, most of the problems of the German federalism leading to the reform persist and important aims have not been achieved. German federalism suffers mostly from deficits in constitutional negotiations, which hardly differ from normal intergovernmental politics, and judicial overload rendering the whole system too inflexible and making necessary constitutional evolution difficult to realize. Any judgment on the UK and Spain must be viewed as preliminary, as both countries are still amidst an intense change process. The asymmetry among the competences of the sub-national units triggers a constitutional dynamics which is - at least currently - not met in formal reform. Rather, changes are implicit, and it is still unclear how the legitimizing basis can be gained to transform the dynamics into evolution which might then contribute to stabilizing the emerging federal system. Both countries have not yet found an appropriate balance of implicit constitutional change and constitutional reform that is required in order to maintain a stable but flexible federalism.

As these considerations show, there is no simple link between a pattern of reform and evolution on the one hand and federal stability on the other. Rather, the pattern chosen must conform to the particular problems and conditions in every country. Further research might reveal more precisely the interrelation 
between a country's conflict structure, its institutional setting, the pattern of constitutional reform and evolution and its long-term stability.

\section{References}

Ackerman, Bruce. 1991. We the People 1. Foundations. Cambridge: Harvard University Press.

Agranoff, Robert, ed. 1999. Accomodating Diversity: Asymmetry in Federal States. Baden Baden: Nomos.

Auel, Katrin. 2008. Finally an exit from the joint decision trap? The German federalism reform. German Politics 17: 424439.

Bednar, Jenna. 2005. Federalism as a public good. Constitutional Political Economy 16: 189205.

Benz, Arthur. 2005. Kein Ausweg aus der Politikverflechtung? Warum die Bundess taatskommission scheiterte, aber nicht scheitern musste. Politische Vierteljahresschrift 46: 20717.

. 2008a. From joint decision traps to over regulated federalism Adverse effects of a successful constitutional reform. German Politics 17: 44056.

. 2008b. German dogmatism and Canadian pragmatism? Stability and constitutional change in federal systems. polis No. 63. Hagen: FernUniversitat in Hagen. http:// www.fernuni hagen.de/polwiss/institut/veroeffentlichungen/ (accessed on September 30, 2009).

Bradbury, Jonathan. 2006. Territory and power revisited: Theorising territorial politics in the United Kingdom after devolution. Political Studies 54: 55982.

Braun, Dietmar. 2003. Dezentraler und unitarischer Foderalismus. Die Schweiz und Deutschland im Vergleich. In Schweizer Foderalismus in vergleichender Perspektive. Special Issue No. 9 of Swiss Political Science Review, ed. Adrian Vatter and Sonja Walti, 5789.

. 2008. Verfassungsanderung trotz vieler Veto Spieler: Foderalismusreform in der Schweiz. In Jahrbuch fur Handlungs und Entscheidungstheorie, ed. Susumu Shikano, Joachim Behnke and Thomas Brauninger, 87 118. Wiesbaden: VS Verlag.

Brouillet, Eugénie. 2005. La négation de la nation. L'identité culturelle québécoise et le fédéralisme canadien. Quebec: Septentrion.

Buchanan, James M., and Gordon Tullock. 1962. The Calculus of Consent. Logical Foundations of Constitutional Democracy. Ann Arbor: University of Michigan Press.

Burkhart, Simone, and Philip Manow. 2006. Was bringt die Foderalismusreform? Koln: MPIfG Working Paper 06/6. http://www.mpifg.de/pu/workpap/wp06 6/wp06 6.html.

Colino, César. 2006. Den spanischen Foderalismus vertiefen oder transformieren? Die neue Reformrunde und die Herausforderungen fur den Autonomiestaat. In Jahrbuch des Foderalismus. Band 7, ed. Europaisches Zentrum fur, Foderalismusforschung, 385403. Baden Baden: Nomos.

Cooter, Robert. 2000. The Strategic Constitution. Princeton: Princeton University Press. 
De Figueiredo, Rui J., and Barry R. Weingast. 2005. Self enforcing federalism. Journal of Law, Economics, and Organization 21: 10335.

Deutsch, Karl M. 1957. Political Community in the North Atlantic Area. Princeton: Princeton University Press.

Devolution Programme. 2008. Final Report. http://www.devolution.ac.uk/final report.htm.

Eidgenossisches Finanzdepartment (EFD). 2004. Informationsbroschure zur Abstimmungs vorlage vom 28. November 2004. Bern: EFD.

Elster, Jon. 1995. Forces and mechanisms in the constitution making process. Duke Law Journal 45: 36496.

Filippov, Mikhail, Peter C. Ordeshook, and Olga Shvetsova. 2004. Designing Federalism. Cambridge: Cambridge University Press.

Foley, Michael. 1989. The Silence of Constitutions. London: Routledge.

Frank, Thomas M. 1968. Why federations fail. In Why Federations Fail. An Inquiry into the Requisites for Successful Federalism, ed. Thomas M. Frank, 167 99. New York: New York University Press.

Freiburghaus, Dieter. 2005. Bedingungen fur eine gelingende Foderalismusreform: Die Neugestaltung des Finanzausgleichs und der Aufgabenteilung zwischen Bund und Kantonen in der Schweiz. In Jahrbuch des Foderalismus 2005. Band 6, ed. Europaisches Zentrum fur Foderalismusforschung, 506 15. Baden Baden: Nomos.

Friedrich, Carl Joachim. 1968. Trends of Federalism in Theory and Practice. New York: Praeger.

Georgii, Harald, and Sarab Borhanian. 2006. Zustimmungsgesetze nach der Foderalismusreform. Berlin: Wissenschaftliche Dienste des Deutschen Bundestages.

Héritier, Adrienne. 2007. Explaining Institutional Change in Europe. Oxford: Oxford University Press.

Honnige, Christoph, Sascha Kneip, and Astrid Lorenz, eds. forthcoming. Verfassungswandel im Mehrebenensystem. Wiesbaden: VS Verlag.

Hrbek, Wolfgang. 2006. Ein neuer Anlauf zur Foderalismus Reform: Das Kompromisspaket der Großen Koalition. In Jahrbuch des Foderalismus. Vol. 7, ed. Europaisches Zentrum fur Foderalismusforschung, 139 57. Baden Baden: Nomos.

Hrbek, Rudolf, and Annegret Eppler, eds. 2005. Die unvollendete Foderalismus Reform. Tubingen: EZFF Selbstverlag.

Johnson, Nevil. 2004. Reshaping the British Constitution. Basingstoke: Palgrave Macmillan.

Kavalski, Emilian, and Magdalena Zolkos, eds. 2008. Defunct Federalisms. Aldershot: Ashgate.

Lazar, Harvey, ed. 1997. Canada: The State of Federation 1997. Non Constitutional Renewal. Kingston: Institute of Intergovernmental Relations.

Lehmbruch, Gerhard. 2000. Parteienwettbewerb im Bundesstaat. Opladen: Westdeutscher Verlag. 
Lemco, Jonathan. 1991. Political Stability in Federal Governments. New York: Praeger.

Lijphart, Arend. 1977. Democracy in Plural Societies. A Comparative Exploration. New Haven: Yale University Press.

Livingston, William S. 1956. Federalism and Constitutional Change. Oxford: Clarendon Press.

Lorenz, Astrid. 2004. Stabile Verfassungen? Konstitutionelle Reformen in Demokratien. Zeitschrift fur Parlamentsfragen 35: 44868.

Lutz, Donald S. 1995. Toward a theory of constitutional amendment. In Responding To Imperfection The Theory of Constitutional Amendement, ed. Sanford Levinson, 23774. Princeton: Princeton University Press.

Marks, Gary, Liesbet Hooghe and Arjan H. Schakel. 2008. Patterns of regional authority. Regional and Federal Studies 18: 16781.

Moreno, Luis. 2001. The Federalization of Spain. London: Routledge.

Mueller, Dennis C. 1999. On amending constitutions. Constitutional Political Economy 10: 38596.

Poirier, Johanne. 2004. Intergovernmental agreements in Canada. At the crossroads between law and politics. In Canada: The State of the Federation 2002, ed. J. Peter Meekison, Hamish Telford, and Harvey Lazar, 425 62. Montreal/Kingston: McGill Queen's University Press.

Rhinow, René. 2003. Auswirkungen der Neugestaltung des Finanzausgleichs und der Aufgabenteilung zwischen Bund und Kantonen (NFA) auf die Parlamente: Hauptreferat. Parlament 6: 59.

Riker, William H. 1964. Federalism: Origin, Operation and Significance. Boston: Little, Brown \& Company.

Risse, Horst. 2007. Zur Entwicklung der Zustimmungsbedurftigkeit von Bundesgesetzen nach der Foderalismusreform 2006. Zeitschrift fur Parlamentsfragen 38: 70711.

Rodden, Jonathan. 2006. Hamilton's Paradox. The Promise and Peril of Fiscal Federalism. Cambridge: Cambridge University Press.

Russell, Peter. 2004. Constitutional Odyssey. Can Canadians become a Sovereign People? Toronto: University of Toronto Press.

Scharpf, Fritz W. 1988. The joint decision trap. Lessons from German federalism and European integration. Public Administration 66: 23978.

. 1997. Games Real Actors Play. Actor Centered Institutionalism in Policy Research. Boulder: Westview Press.

. 2005. No Exit from the Joint Decision Trap? Can German Federalism Reform Itself? Koln: MPIfG Working Paper 05/8. http://www.mpi fg koeln.mpg.de/pu/workpap/wp05 8/ wp05 8.htm.

. 2006. Foderalismusreform: Weshalb wurde so wenig erreicht? Aus Politik und Zeitgeschichte 50: 611 . 
Simeon, Richard. 2006. Federal Provincial Diplomacy. The Making of Recent Policy in Canada. Toronto: University of Toronto Press.

Stein, Michael B. 1997. Improving the process of constitutional reform in Canada: lessons from the Meech Lake and Charlottetown constitutional rounds. Canadian Journal of Political Science 30: 30738.

Trench, Alan. 2008. Finding a Voice for Wales: Assessing three Phases of Constitutional Development in Wales. Rennes: Paper presented at the ECPR Joint Sessions of Workshops.

Tsebelis, George. 2002. Veto Players. How Political Institutions Work. Princeton: Princeton University Press.

Vatter, Adrian, and Sonja Walti. 2003. Schweizer Foderalismus in vergleichender Perspektive Der Umgang mit Reformhindernissen. In Schweizer Foderalismus in vergleichender Perspektive. Special Issue No. 9 of Swiss Political Science Review, ed. Adrian Vatter and Sonja Walti, 125.

Voigt, Stefan. 1999. Explaining Constitutional Change: A Positive Economics Approach. Cheltenham: Edward Elgar.

Watts, Ronald L. 1977. Survival or disintegration. In Must Canada Fail, ed. Richard Simeon, 42 62. Montreal: McGill Queen's University Press.

. 2008. Comparing Federal Systems. Montreal: McGill Queen's University Press.

Wettstein, Gérard. 2002. Die Neugestaltung des Finanzausgleichs und der Aufgaben (NFA) Erfolgsfaktoren und Hurden aus Sicht der Projektleitung. Leges 13: 3542. 